\title{
JOB INSECURITY: REVIEW OF THE INTERNATIONAL LITERATURE ON DEFINITIONS, PREVALENCE, ANTECEDENTS AND CONSEQUENCES
}

\author{
HANS DE WITTE \\ Hans.Dewitte@psy.kuleuven.be \\ Research Center on Stress, Health and Well-Being \\ Department of Psychology \\ Katholieke Universiteit Leuven \\ Belgium
}

\begin{abstract}
This article reviews the literature on job insecurity. After defining the concept and its components, the prevalence of job insecurity among workers is discussed. Next, various antecedents are charted, and the consequences of job insecurity for the health and well-being of individuals and for their attitudes and behaviours towards organisations are discussed. Finally, some practical suggestions are made in order to reduce the harmful effects of insecurity, and some suggestions for future research are formulated. The focus of this review article is on studies from Europe and the U.S. As such, it aims to introduce the field of job insecurity to South African researchers.
\end{abstract}

\section{OPSOMMING}

Die artikel gee 'n oorsig van die literatuur oor werksonsekerheid. Na die defineering van die konsep en die komponente, word die voorkoms van werksonsekerheid onder werknemers bespreek. Volgende word verskeie antesedente bespreek, en die gevolge van werksonsekerheid op die gesondheid en welstand van individue, hul gesindhede en hul gedrag teenoor die organisasie bespreek. Laastens word daar ' $n$ paar praktiese voorstelle gemaak om die skadelike gevolge van onsekerheid te verminder, asook voorstelle vir toekomstige navorsing. Die fokus van hierdie oorsig artikel is op studies in Europa and die VSA gemaak, en as sulks beoog dit om die veld van werksonsekerheid aan Suid-Afrikaanse navorsers voor te stel.

In the course of the past decades, numerous studies have examined the psychological effects of work and unemployment. Research showed that well-being is hampered by unemployment (e.g. Fryer, 2000; Warr, 1984 \& 1987). Occupational health psychology analyzed the work conditions leading to a decrease in well-being, and an increase in burnout and job dissatisfaction (Kompier, 2003; Le Blanc, de Jonge \& Schaufeli, 2000). The topic of job insecurity is situated between employment and unemployment, because it refers to employed people who feel threatened by unemployment. Around this topic, an extensive research tradition originated since the 1980's (e.g. Hartley, Jacobson, Klandermans \& van Vuuren, 1991; Klandermans \& van Vuuren, 1999). This is hardly surprising. Job insecurity became a sizeable social phenomenon, caused by fundamental changes in the economic system of most European countries and the U.S., such as plant closures, company restructuring and the increase in temporary contracts. As a consequence, disciplines like psychology were forced to analyze and document its origins and consequences. In this contribution, the results of psychological research on the prevalence, causes and consequences of job insecurity are reviewed. The concluding section of this article also contains some suggestions for practice, by discussing interventions that could reduce the negative consequences of job insecurity. Suggestions for future research on the subject are also discussed. This review article focuses on research originating from Europe and the U.S. Research on job insecurity is fairly scarce in South Africa thus far. As a consequence, it seemed relevant to make a 'state of the art' in this field in order to set the scene for South African researchers. This special issue contains several recent studies conducted in South Africa, which will answer to these challenges, showing that the scientific analysis of job insecurity is starting to develop into a new and growing research tradition in South Africa too.

\section{Definition of job insecurity}

Job insecurity or 'the threat of unemployment' is defined in various ways in the literature. Greenhalgh and Rosenblatt (1984,

Requests for copies should be addressed to: H De Witte,

Hans.DeWitte@psy.kuleuven.be p. 438) define job insecurity as "the perceived powerlessness to maintain the desired continuity in a threatened job situation". Heany, Israel and House (1994, p. 1431) refer to the "perception of a potential threat to the continuity of the current job", and Sverke, Hellgren and Näswall (2002, p. 243) to the "subjectively experienced anticipation of a fundamental and involuntary event related to job loss". In this article, job insecurity is defined as the perceived threat of job loss and the worries related to that threat (see also: De Witte, 1999, p. 156; Sverke, Hellgren, Näswall, Chirumbolo, De Witte \& Goslinga, 2004, p. 39). This definition is closely related to the common denominator of most definitions in this field: the concern regarding the future continuity of the current job (see e.g. Sverke \& Hellgren, 2002; van Vuuren, 1990). Most authors also agree on a number of additional aspects. First of all, job insecurity is a subjective perception. The same objective situation (e.g. a decline in company orders) may be interpreted in various ways by different workers. It may provoke feelings of insecurity for some, whereas their job continuity is ('objectively speaking') not at stake. Others, on the contrary, may feel particularly secure about their jobs, even though they will be dismissed soon afterwards. Subsequently, what typifies this subjective conceptualisation of job insecurity is that it concerns insecurity about the future: Insecure employees are uncertain about whether they will retain or lose their current job. They are 'groping in the dark' as far as their future within the organisation or company is concerned. This perception contrasts to the certainty of dismissal. The information that one has been given notice enables the employee to take concrete action in order to cope with the situation (e.g. by looking for other jobs). Employees who feel uncertain cannot adequately prepare themselves for the future, since it is unclear to them whether actions should be undertaken or not. Many definitions also refer to the involuntary nature of job insecurity (e.g. Greenhalgh \& Rosenblatt, 1984; Sverke \& Hellgren, 2002). Research on job insecurity does not focus on employees who deliberately choose an uncertain job status (e.g. prefer to work with a temporary contract, because it suits their present situation). Insecure employees rather experience a discrepancy between the preferred and the perceived level of 
security offered by their employer. A feeling of powerlessness is also emphasized in many definitions (e.g. Greenhalgh \& Rosenblatt, 1984). Job insecurity mostly implies feelings of helplessness to preserve the desired job continuity.

Scientific views however differ regarding some other components of job insecurity. Some differentiate between the cognitive probability of losing one's job (e.g. 'I think that I will be dismissed'), and the affective experience thereof (e.g. 'I am worried that I will become unemployed') (e.g. Borg, 1992). Others differentiate between quantitative and qualitative job insecurity (Hellgren, Sverke \& Isaksson, 1999). Quantitative job insecurity refers to the continuity (or loss) of the job itself: People are uncertain about whether they will be able to retain their actual job or become unemployed. Qualitative job insecurity refers to insecurity regarding the continued existence of valued aspects of the job, such as pay, working hours, colleagues and the job content (e.g. autonomy, responsibility). Research focussed on the differential consequences of cognitive versus affective job insecurity (Borg, 1992) and of quantitative versus qualitative insecurity (Hellgren et al., 1999). This review of the literature, however, will concentrate on quantitative job insecurity.

\section{Prevalence of job insecurity}

To what extent is the working population subjected to feelings of job insecurity? Because job insecurity does not necessarily lead to unemployment, the job-insecure population may be considerably larger than the number of employees who actually lose their job. Estimates of the number of job-insecure employees vary between countries. In 1996, no less than $38 \%$ of the employees of one of the 30 member states of the Organisation for Economic Co-operation and Development (OECD) found that their company offered them less job security than most other companies in the same sector (OECD, 1997, p. 134-135). Within European countries this percentage fluctuated between 23 and $46 \%$, with a median of $38 \%$. When the question is narrowed down towards the individual job, these percentages drop as a rule. In a recent comparative European study, $9.4 \%$ of the employed respondents stated that they perceived a 'very' or 'rather' large probability of becoming unemployed in the near future. About $75 \%$ estimated the chances of becoming unemployed as being 'rather' or 'very' small (De Weerdt, De Witte, Catellani \& Milesi, 2004). These percentages fluctuated between the participating countries, with $5.1 \%$ of job-insecure workers in Belgium and $14.5 \%$ in Hungary. These numbers suggest that job insecurity concerns only a small part of the employed population. In absolute numbers, a large number of employees are concerned, however. Approximately 9\% of jobinsecure employees in Europe amounts to a volume of several million employees. Note that the perception of job insecurity also increased in most European countries during the last five years (De Weerdt et al., 2004). Taken together, these findings suggest that job insecurity concerns an important minority of the working population. Whether this perception also impacts upon their well-being and attitudes will be assessed further on in this review.

\section{Antecedents of job insecurity}

In this article, job insecurity is described as a subjective perception. This conceptualisation of job insecurity initiated a research tradition into the causes or antecedents of (perceived) job insecurity (e.g. Ashford, Lee \& Bobko, 1989; Hartley et al., 1991). These antecedents are often divided into three levels: Variables on a macro level, such as the region or the organisation (e.g. the national or regional degree of unemployment and changes in the organisational structure), individual background characteristics, which determine the employee's position in the company ('positional' variables, such as age, length of service and occupational level), and personality traits.

Psychologists are often attracted to the analysis of the impact of personality traits as antecedents of job insecurity, since these variables fit their disciplinary viewpoint and expertise. The analysis of personality traits as antecedents of job insecurity also fits the definition of insecurity as a subjective phenomenon, because such a perception is probably influenced by the individual's personality. Research indeed shows that especially the traits of locus of control and negative affectivity are associated with perceived job insecurity (for an overview, see Hartley et al., 1991; Sverke, Hellgren, Näswall, Chirumbolo, De Witte \& Goslinga, 2004). Individuals with an internal locus of control experience control over their lives, which reduces their perception of job insecurity. Negative affectivity is also associated with job insecurity. Individuals displaying this trait exhibit a general tendency to see themselves and their environment from a negative point of view. This attitude spills over to their work life, and as a consequence, they perceive more insecurity.

It would be a mistake, however, to reduce job insecurity to a perception that is solely caused by personality. Job insecurity is not just something 'in your head'. This perception largely results from the 'objective' conditions in which people work. According to research, the most important antecedents are macro and positional variables (Ashford et al., 1989; Hartley et al., 1991). A recent analysis of various Finnish databanks between 1997 and 2003 revealed a clear correlation between the subjective perception of job insecurity and the national percentage of unemployment at a given time (Nätti, Happonen, Kinnunen \& Mauno, 2005). Research in which various European countries were compared also suggests job insecurity to reflect the national level of unemployment and economic situation (De Weerdt et al., 2004). Moreover, research consistently shows that job insecurity correlates with specific background characteristics (or 'positional' variables) which indicate a vulnerable labour market position. Research (e.g. Näswall \& De Witte, 2003) shows that blue collar-workers, low skilled individuals, employees in the industrial sector and those with a temporary job contract, more often perceive themselves as job-insecure. These associations are no coincidence. These categories of employees indeed have a higher probability of being dismissed. This suggests that job insecurity is a good reflection of an individual's real (or 'objective') chances and position on the labour market, despite its subjective nature.

\section{CONSEQUENCES FOR HEALTH AND WELL-BEING}

\section{Overall results}

Quite an extensive research tradition has developed in the course of the past decades, documenting the negative consequences of job insecurity for individual workers (for an overview, see e.g. De Witte, 1999; Nolan, Wichert \& Burchell, 2000; Sverke \& Hellgren, 2002; Sverke et al., 2004). Job insecurity is considered a work stressor in various theoretical models of work psychology (e.g. Karasek \& Theorell, 1990; Siegrist, 1996; Warr, 1987). Therefore, it is not surprising that job insecurity has a negative impact on employees' health and well-being. Research first of all shows that job insecurity correlates consistently with a lower score on various indicators of well-being at work. Especially the negative correlation with job satisfaction, which is found in nearly every study, is conspicuous (e.g. Ashford et al., 1989; Davy, Kinicki \& Scheck, 1997; Rosenblatt, Talmud \& Ruvio, 1999). Parallel to this finding is the finding of higher burnout scores among the jobinsecure (e.g. Dekker \& Schaufeli, 1995; De Witte, 2000). Next, research also shows that general indicators of psychological wellbeing (e.g. Büssing, 1999; Hellgren et al., 1999) and life satisfaction (Lim, 1997) are lower amongst job-insecure workers. In other research (e.g. Burchell, 1994; Hartley et al., 1991; Landsbergis, 1988; van Vuuren, 1990) an increased level of irritation and anxiety, and of psychosomatic as well as physical complaints (varying from increased blood pressure to heart disorders) are added to this list. 
Some refining is in order, however, when discussing the consequences of job insecurity for the well-being of individuals. The preceding review could create the impression that job insecurity affects all possible indicators of health and well-being to the same extent. That is not the case. A recent meta-analysis of 72 studies regarding the consequences of job insecurity shows that especially work-related well-being is (negatively) correlated with job insecurity (Sverke, Hellgren \& Näswall, 2002). The established meta-correlation between job insecurity and job satisfaction amounted to no less than -.41. With indicators of the broader concept of psychological wellbeing, this meta-correlation drops to -.24 , and with indicators of psychosomatic or physical health to 'only' -.16. All the correlations mentioned are statistically significant, however, indicating that job insecurity is problematic for employees' well-being as well as their health, even though its influence seems to be especially pronounced regarding 'occupational well-being'. A second refinement concerns the relative nature of the reported effects. Job-insecure employees are not necessarily dissatisfied or unhappy. Rather, they are less satisfied and less happy than employees who feel secure about their jobs. Thus, 62 to $63 \%$ of job-insecure employees in a Belgian research reported that they were very satisfied with their job and with their life (De Witte, 2003). These percentages were however significantly higher amongst job-secure employees (88 and $84 \%$ respectively), illustrating the relative difference between both groups.

\section{Some additional issues}

The association between job insecurity and low well-being discussed in the preceding part of this article, raises a number of additional questions. The studies reviewed suggest job insecurity to be a stressor at the workplace. The question arises as to the relative importance of job insecurity in comparison to other work related stressors. After all, occupational health psychology identified a large number of work stressors, of which job insecurity is just one example (see e.g. de Jonge, Le Blanc \& Schaufeli, 2003; Warr, 1987). Research that compares the influence of job insecurity with that of other stressors, suggests that job insecurity is 'one of the least important amongst the most important stressors' (De Witte, 1999, p. 173-174). Once background characteristics and other work stressors had been statistically kept under control, job insecurity appears to exert a significant and autonomous influence on the working respondents' psychological well-being. Amongst the statistically significant stressors, job insecurity did not, however, constitute the most problematic aspect. The detrimental effects of workload and underutilisation of skills were more important.

A second question regards the relation between the consequences of job insecurity and unemployment for the employee's well-being. As mentioned before, unemployment has a negative impact on psychological well-being (e.g. Fryer, 2000; Warr, 1984). One of the traditional assumptions in stress research is that the consequences for well-being of the anticipation of a negative event may be as powerful as the event itself (Lazarus \& Folkman, 1984). Research suggests that this indeed applies to job insecurity. A comparison between the mental health scores of unemployed and job-insecure employees in Flanders, produced no difference (De Witte, 1999). These findings underline the problematic nature of job insecurity: Fearing that one will lose one's job seems as aggravating as to actually be unemployed!

A final question relates to the validity of the reported correlation between job insecurity and life satisfaction. Research shows that job insecurity correlates negatively with both joband life satisfaction. Research, however, also shows a strong correlation between job satisfaction and life satisfaction (the 'spill over'-hypothesis; see e.g. Spector, 1997). A question that rises is whether job insecurity still correlates with life satisfaction once (the correlation with) job satisfaction has been kept under control. Research suggests this indeed to be the case (De Witte, 2003). This implies that the influence of job insecurity is not just limited to well-being at work, but also (autonomously) affects broader aspects of well-being, such as life satisfaction. This impact on aspects outside the workplace is however more limited than the impact on work-related wellbeing, as suggested by the results of the meta-analysis mentioned earlier (Sverke et al., 2002)

\section{Job insecurity causes lower well-being}

In the preceding paragraphs, it was implicitly assumed that job insecurity causes a reduction in well-being and health. This suggestion is legitimate. Longitudinal research on the consequences of job insecurity enables us to determine the direction of the association between job insecurity and well-being (e.g. Burchell, 1994; Iversen \& Sabroe, 1988; van Vuuren, 1990). Three important conclusions can be drawn from such studies.

Longitudinal research first of all shows that the impact of job insecurity on health and well-being is more pronounced than the reverse influence of well-being and health on the perception of job insecurity. This leads to the conclusion that job insecurity causes a reduction of well-being, instead of the other way round. This is illustrated by a recent study by Hellgren and Sverke (2003) that compared various models of the relationship between job insecurity and well-being. The results showed that the model in which job insecurity at time 1 influenced psychological well-being at time 2 fitted the data best.

A second important conclusion emerging from longitudinal research is that job insecurity is more problematic for well-being than the certainty of dismissal (Dekker \& Schaufeli, 1995). This study investigated employees who were insecure about their jobs at time 1 . At the second measurement moment two months later, it had become clear that one group would be dismissed, while it remained uncertain what would become of the second group. It was striking that the well-being of the first group increased once they had clarity about the future of their job (e.g. certainty about dismissal). This group could start preparing to cope with their dismissal and begin to look for a new job. For the second group, the insecurity remained at the same level as before. Their well-being was just as low as at time 1 (first measurement moment). This suggests that employees prefer certainty to insecurity, even if the content of this certainty is negative. The reason for this probably relates to the perception that certainty enables to regain control over one's own life and future (see further on).

Finally, job insecurity also emerges as a chronic stressor (van Vuuren, 1990). Insecurity about one's job is harmful to wellbeing in the short as well as the long-term. Insecurity experienced at two points in time exerts a cumulative influence on future well-being. Employees who expressed insecurity at two points in time in the research of van Vuuren (1990), displayed the lowest level of well-being. In her research, the negative effect on well-being also increased as employees' insecurity persisted.

\section{Theoretical explanations for the detrimental consequences} of job insecurity

The negative consequences of job insecurity can be explained on the basis of three theoretical perspectives. Quantitative job insecurity implies the perception that employees may lose their current job. It is not surprising that this perception is experienced in a negative way. In most contemporary societies, a job holds the key to social integration, social participation and recognition. This notion is at the core of Jahoda's latent deprivation model (Jahoda, 1982). In this model, Jahoda documents the needs which can be satisfied by employment, such as earning an income, having social contacts outside the family, being able to structure one's time and to develop individually and socially. The threat of unemployment implies the frustration of these needs, and is hardly an attractive future perspective. 
Other factors also play a role, stemming from job stress research. Furda and Meijman (1992) suggested two such explaining factors: Predictability and controllability. Job insecurity first of all implies unpredictability. It is not clear to the person concerned what will happen in the future. This makes it difficult to react adequately, because it is unclear whether one should undertake something or not. In his 'vitamin'-model, Warr distinguishes nine aspects of the work situation which influence psychological well-being (Warr, 1987). The aspect 'environmental clarity' refers to predictability. Warr shows that a lack of environmental clarity (and therefore unpredictability) reduces psychological well-being. Next to unpredictability, uncontrollability plays an even greater part. Various authors consider the lack of control (or the powerlessness experienced) to deal with the threat as the core of job insecurity (e.g. Dekker \& Schaufeli, 1995; Greenhalgh \& Rosenblatt, 1984). Uncontrollable stressors are more problematic for well-being than unpredictable ones, because the employee cannot do anything to reduce their aggravating nature. This may also explain why well-being increases for those who obtain certainty about their dismissal, after a lengthy period of insecurity. For them, the future becomes controllable again, because they know what will happen to them.

Finally, psychological contract theory also seems relevant (Sverke et al., 2004; van Vuuren, 1990). The psychological contract refers to the perceived mutual obligations between employer and employee (Rousseau, 1995). Within the traditional psychological contract, which dominates most Western societies, the exchange between security (on the part of the employer) and loyalty (on the part of the employee) is crucial. Employees thus perceive the experience of job insecurity as a violation of the psychological contract with their employer (Sverke et al., 2004). Such a violation has negative consequences for the well-being of the employee concerned, as well as for his or her commitment to the employer in question (e.g. Wanous, Poland, Premack \& Davis, 1992).

\section{CONSEQUENCES FOR ORGANISATIONS}

Job insecurity also influences various organisational attitudes and behaviours, which has consequences for the organisation too. The perception of job insecurity is frequently associated with a deterioration in organisational commitment (e.g. Sverke et al., 2004), distrust of company management (Ashford et al., 1989), resistance against organisational change (Greenhalgh \& Rosenblatt, 1984), a performance decrease (De Witte, 2000) and a reduction in organisational citizenship behaviours (Bultena, 1998). Likewise, job insecurity seems to strengthen employees' intention to leave the company (e.g. Davy et al., 1997). These attitudinal and behavioural consequences of job insecurity threaten the survival of the organisation (Greenhalgh \& Rosenblatt, 1984). Dissatisfied and less committed employees are less dedicated to the company and its goals, and tend to ruin its social atmosphere. Additionally, research shows that especially the best qualified members of the workforce try to leave the company as soon as possible, because they have better chances of finding a job elsewhere (Greenhalgh \& Rosenblatt, 1984). Their departure however further weakens the organisation's strength and creates new costs, because (expensive and time-intensive) new recruiting efforts have to be made once again.

The conclusion that job insecurity affects organisational attitudes and behaviours, can also be explained in various ways. These reactions could indicate a form of resentment on the part of the employee, because he or she experiences a violation of the psychological contract with the employer (Sverke et al., 2004; van Vuuren, 1990). As mentioned before, job security is one of the components of the traditional psychological contract between employer and employee. When less security is offered, the employee may attempt to restore the resulting imbalance by showing less involvement, less motivation, and by lowering his or her performance. Reduced company involvement could also be interpreted as a (passive) coping strategy. By psychologically withdrawing from the organisation, the aggravating nature of an eventual job loss is reduced beforehand (the 'disinvolvement syndrome', see Greenhalgh \& Rosenblatt, 1984).

\section{REDUCING THE NEGATIVE CONSEQUENCES OF JOB INSECURITY}

The preceding sections of this article documented the problematic nature of job insecurity. In consequence, psychologists should develop suggestions and interventions to counter its negative effects. Given the economic origins of job insecurity, this is no sinecure, however. Job insecurity is the result of worldwide economical changes, which affect all contemporary societies. In the near future, these changes will probably increase rather than decrease in magnitude. These evolutions emphasise both the complexity and the necessity of interventions to reduce its consequences.

Job insecurity is problematic because it implies unpredictability and uncontrollability. This theoretical explanation allows the formulation of some practical recommendations. By reducing unpredictability and uncontrollability, the negative consequences of job insecurity could be avoided or at least mitigated. There are at least three ways in which this can be achieved: By communication, by participation in decision making and by increasing organisational justice. Insecurity is stimulated by a lack of communication about future events. Research suggests that explicit and open communication regarding e.g. organisational changes is effective in reducing insecurity (Schweiger \& DeNisi, 1991). Open, honest and early communication increases the predictability and controllability of future events. Additionally, such a communication increases the perception that one is respected as an employee. Participation in decisions about the organisation's future (and thus about employment) also reduces insecurity (Parker, Chmiel \& Wall, 1997). By participating, employees increase their control over the situation. Participation in the decision-making process also heightens the predictability of events. Communication and participation also strengthen the perception that employees are treated fairly by the employer ('organisational justice'; see Greenberg \& Lind, 2000). Following the correct procedures ('procedural justice') is of special importance here, because such procedures improve the predictability of the organisational change processes and their outcomes.

The previous suggestions aimed to reduce the phenomenon of job insecurity as such. This is not wholly possible, however. A certain degree of insecurity and obscurity is perhaps unavoidable in economically troubled times. It may therefore be useful to develop additional interventions to mitigate (or buffer) the negative consequences of job insecurity. In the literature, various moderator variables are suggested which could weaken the negative impact of job insecurity on wellbeing. Social support by family and colleagues can play such a role (Lim, 1996). Also the development of employees' capacities to cope with organisational changes appears important. Organisational changes are an inherent part of economic development, making it important to strengthen employees' capacity to manage such changes in a constructive way. Improving employees' 'employability' can also play an important role. Employability refers to the development of professional skills in general (such as e.g. language competence), but also to the acquisition of interpersonal skills, such as learning to cope with change. Research suggests that employability can indeed buffer the negative consequences of job insecurity on health (Silla, Gracia, Peiró, De Witte \& De Cuyper, in review). 
A last possible intervention is offered by Siegrist's 'Effort Reward Imbalance'-model (1996), which suggests that the negative consequences for well-being result from an imbalance between efforts and rewards in the work situation. Job insecurity belongs to the reward-side of this equation. An imbalance between efforts and rewards can be resolved in two ways. The presence of insecurity could be compensated by increasing other rewards, such as pay or status. The lack of balance could also be restored by reducing efforts, e.g. by decreasing workload (by redistributing tasks or by recruiting new employees). These balancing exercises are probably not very realistic in times of economic cutbacks, however. Each of the suggested adjustments has cost implications for the organisation, which may be difficult to realize.

\section{CONCLUSION AND DISCUSSION}

This contribution reviewed the literature on the definitions, prevalence, antecedents and consequences of job insecurity. Job insecurity is a phenomenon which affects a sizeable minority of employees. It has a negative effect on individual well-being and on organisational attitudes and behaviours. Job insecurity is the result of radical economic changes. The fundamental transformation of the economy in most contemporary societies is not likely to disappear in the near future. As a consequence, employees will be confronted with job insecurity and its consequences for a long time to come. This urges psychologists to develop interventions to cope with this issue and its consequences, and to increase research efforts in order to understand this phenomenon, and its underlying processes.

To date, research on the consequences of job insecurity has focused especially on the well-being and health of individual employees. Attention has also been given to organisational consequences. Reviewing this field, suggests that it becomes necessary to broaden the focus of future research. First of all, it seems worthwhile to investigate the consequences of job insecurity for the employee's family: What is the impact of job insecurity on partners and children? What are the effects of job insecurity on broader social networks, such as neighbours, friends and participation in volunteer work? Also the impact of job insecurity on employees' union involvement and participation had inspired markedly little research (but see De Witte, 2005; Sverke et al., 2004). This is quite conspicuous because the union movement occupies a crucial position in most Western economic systems, and can play an important role to reduce job insecurity and its consequences. Finally, one should also analyse the social consequences of job insecurity. Research in Flanders (Belgium) suggests that the dissatisfaction resulting from job insecurity may increase intolerant social attitudes, which in turn may lead to a preference for extreme-right political parties (De Witte, Hooge, Vandoorne \& Glorieux, 2001). Broadening the focus also means that one should invest more in international comparative research on the antecedents and consequences of job insecurity. Within the European Union, countries differ quite strongly in structural and cultural terms. Adding countries from other continents (such as South Africa) to these comparisons, will even increase the possibilities to analyse this issue. Researchers could also focus more thoroughly at regional differences within the same country. All these comparisons are important for the development of science in this field, as they allow to test theories in different contexts. This has two important advantages. This first of all enables to determine the extent to which the actual scientific knowledge in this field may be generalized. Secondly, specific (regional and national) explanations can be traced, allowing to expand existing theoretical frameworks.

Besides broadening research efforts, it is perhaps also necessary to gain more in-depth knowledge on job insecurity. Much of the research into the consequences of job insecurity is strongly descriptive in nature. Scientific knowledge about the consequences of job insecurity would benefit from future research with a more theoretically orientated approach. This implies more thorough and more consistent testing of existing theories in future research. There is also room for further theoretical development and for the application of theoretical frameworks from other fields in psychology, such as social and motivational psychology. To conclude, it seems worthwhile to pay more attention to the explicit test of the effects of various moderators. The detection of moderators - variables which reduce (or increase) the impact of job insecurity on various outcomes variables - has a double aim. On the one hand, it broadens the theoretical knowledge about the way in which job insecurity influences well-being and attitudes. Detecting moderators, on the other hand, is also of practical use, because it provides indications about the variables that have to be influenced or changed, when one aims to reduce the negative consequences of job insecurity.

\section{REFERENCES}

Ashford, S., Lee, C. \& Bobko, P. (1989). Content, causes, and consequences of job insecurity. A theory-based measure and substantive test. Academy of Management Journal, 32 (4), 803829.

Borg, I. (1992). Ueberlegungen und untersuchungen zur messung der subjektiven unsicherheit der arbeitsstelle. Zeitschrift fur arbeits- und organisationspsychologie, 36 (3), 107-116.

Bultena, C. (1998). Social exchange under fire. Direct and moderated effects of job insecurity on social exchange. Dissertation Abstracts International, 59 (4-B), 1894.

Burchell, B. (1994). The effects of labour market position, job insecurity and unemployment on psychological health. In D. Gallie, C. Marsh \& C. Vogler (Eds.), Social change and the experience of unemployment, Oxford: University Press, pp. 188-212.

Büssing, A. (1999). Can control at work and social support moderate psychological consequences of job insecurity? Results from a quasi experimental study in the steel industry. European Journal of Work and Organizational Psychology, 8 (2), 219-242.

Davy, J.A., Kinicki, A.J., \& Scheck, C.L. (1997). A test of job insecurity's direct and mediated effects on withdrawal cognitions. Journal of Organizational Behavior, 18, 323-349.

Dekker, S. \& Schaufeli, W. (1995). The effects of job insecurity on psychological health and withdrawal: A longitudinal study. Australian Psychologist, 30 (1), 57-63.

De Weerdt, Y., De Witte, H., Catellani, P. \& Milesi, P. (2004). Turning right? Socio-economic change and the receptiveness of European workers to the extreme right. Results of a survey in Europe. Leuven: Hoger Instituut voor de Arbeid-KULeuven.

De Witte, H. (1999). Job insecurity and psychological well-being. Review of the literature and exploration of some unresolved issues. European Journal of Work and Organizational Psychology, 8 (2), 155-177.

De Witte, H. (2000). Arbeidsethos en jobonzekerheid: Meting en gevolgen voor welzijn, tevredenheid en inzet op het werk. In R. Bouwen, K. De Witte, H. De Witte \& T. Taillieu (Eds.), Van groep tot gemeenschap. Leuven: Garant, pp. 325-350.

De Witte, H. (2003). Over de gevolgen van werkloosheid en jobonzekerheid voor het welzijn. Empirische toets op basis van de Europese Waardenstudie. Tijdschrift Klinische Psychologie, 33 (1), 7-21.

De Witte, H. (Ed., 2005). Job insecurity, union involvement and union activism. Aldershot: Ashgate.

De Witte, H., Hooge, J., Vandoorne, J. \& Glorieux, I. (2001). Prettig werken in een gezonde samenleving. Omvang, verschillen en gevolgen van arbeidstevredenheid in Vlaanderen. In Administratie Planning en Statistiek (Eds.), Vlaanderen gepeild! De Vlaamse overheid en burgeronderzoek 2001. Brussel: Ministerie van de Vlaamse Gemeenschap, pp. 73-98. 
Fryer, D. (2000). Unemployment and mental health: Hazards and challenges of psychology in the community. In K. Isaksson, C. Hogstedt, C. Eriksson \& T. Theorell (Eds.), Health effects of the new labour market. New York: Kluwer Academic/Plenum Publishers, pp. 11-23.

Furda, J. \& Meijman, T. (1992). Druk en dreiging, sturing of stress. In J. Winnubst \& M. Schabracq (Eds.), Handboek Arbeid en Gezondheid Psychologie. Hoofdthema's. Utrecht : Uitgeverij Lemma, pp. 127-144.

Greenberg, J. \& Lind, E. (2000). The pursuit of organizational justice: From conceptualization to implication to application. In C. Cooper \& E. Locke (Eds.), Industrial and organizational psychology. Linking theory with practice. Oxford: Blackwell, pp. 72-108.

Greenhalgh, L. \& Rosenblatt, Z. (1984). Job insecurity: Toward conceptual clarity. Academy of management review, 9 (3), 438-448.

Hartley, J., Jacobson, D., Klandermans, B. \& van Vuuren, T. (1991). Job insecurity. Coping with jobs at risk. London: Sage Publications.

Heaney, C., Israel, B. \& House, J. (1994). Chronic job insecurity among automobile workers: Effects on job satisfaction and health. Social Science and Medicine, 38 (10), 1431-1437.

Hellgren, J. \& Sverke, M. (2003). Does job insecurity lead to impaired well-being or vica versa? Estimation of cross-lagged effects using latent variable modelling. Journal of Organizational Behavior, 24, 215-236.

Hellgren, J., Sverke, M., \& Isaksson, K. (1999). A twodimensional approach to job insecurity: Consequences for employee attitudes and well-being. European Journal of Work and Organizational Psychology, 8 (2), 179-195.

Iversen, L. \& Sabroe, S. (1988). Psychological well-being among unemployed and employed people after a company closedown: A longitudinal study. Journal of Social Issues, 44 (4), 141-152.

Jahoda, M. (1982). Employment and unemployment. A socialpsychological analysis. Cambridge: University Press.

Karasek, R. \& Theorell, T. (1990). Healthy work. Stress, productivity and the reconstruction of working life. New York: Basic Books.

Klandermans, B. \& van Vuuren, T. (1999). Job insecurity. European Journal of Work and Organizational Psychology, 8 (2), 145-314.

Kompier, M. (2003). Job design and well-being. In M. Schabracq, J. Winnubst \& C. Cooper (Eds.), The handbook of work \& health psychology. (2nd Ed.), Chichester: John Wiley \& Sons, pp. 429-454.

Landsbergis, P. (1988). Occupational stress among health care workers: A test of the job demands-control model. Journal of occupational behaviour, 9, 217-239.

Lazarus, R. \& Folkman, S. (1984). Stress. Appraisal and coping. New York: Springer.

Le Blanc, P., de Jonge, J. \& Schaufeli, W. (2000). Job stress and health. In $\mathrm{N}$. Chmiel (Ed.), Introduction to work and organizational psychology. A European perspective, Oxford: Blackwell, pp. 148-177.

Lim, V. (1996). Job insecurity and its outcomes: Moderating effects of work-based and non work-based social support. Human Relations, 49 (2), 171-194.

Lim, V. (1997). Moderating effects of work-based support on the relationship between job insecurity and its consequences. Work \& Stress, 11 (3), 251-266.
Näswall, K. \& De Witte, H. (2003). Who feels insecure in Europe? Predicting job insecurity from background variables. Economic and Industrial Democracy, 24 (2), 189-215.

Nätti, J., Happonen, M., Kinnunen, U. \& Mauno, S. (2005). Job Insecurity, temporary work and trade union membership in Finland 1977-2003. In De Witte, H. (Ed.), Job insecurity, union involvement and union activism. Aldershot: Ashgate, pp. 11-48.

Nolan, J., Wichert, I. \& Burchell, B. (2000). Job insecurity, psychological well-being and family life. In E. Heery \& J. Salmon (Eds.), The insecure workforce. London: Routledge, pp. 181-209.

OECD (1997). Is job insecurity on the increase in OECD countries? OECD Employment Outlook, July: 129-159.

Parker, S.K., Chmiel, N. \& Wall, T. (1997). Work characteristics and employee well-being within a context of strategic downsizing. Journal of Occupational Health Psychology, 3 (4), 289-303.

Rosenblatt, Z., Talmud, I., \& Ruvio, A. (1999). A gender-based framework of the experience of job insecurity and its effects on work attitudes. European Journal of Work and Organizational Psychology, 8 (2), 197-217.

Rousseau, D. (1995). Psychological contracts in organizations: Understanding written and unwritten agreements. Thousand Oaks, CA: Sage Publications.

Schweiger, D. \& DeNisi, A. (1991). Communication with employees following a merger: A longitudinal field experiment. Academy of Management Journal, 34, 110-135.

Siegrist, J. (1996). Adverse health effects of high-effort/lowreward conditions. Journal of Occupational Health Psychology, 1, 27-41.

Silla, I., Gracia, F., Peiró, J.M., De Witte, H. \& De Cuyper, N. (In review). Job insecurity and health-related outcomes. The moderating role of employability. Manuscript submitted for publication.

Spector, P. (1997). Job satisfaction. Application, assessment, causes, and consequences. London: Sage.

Sverke, M. \& Hellgren, J. (2002). The nature of job insecurity: Understanding employment insecurity on the brink of a new millennium. Applied Psychology: An International Review, 51 (1), 23-42.

Sverke, M., Hellgren, J. \& Näswall, K. (2002). No security: A meta-analysis and review of job insecurity and its consequences. Journal of Occupational Health Psychology, 7 (3): 242-264.

Sverke, M., Hellgren, J., Näswall, K., Chirumbolo, A., De Witte, H. \& Goslinga, S. (2004). Job insecurity and union membership. European unions in the wake of flexible production. Brussels: P.I.E.-Peter Lang.

van Vuuren, T. (1990). Met ontslag bedreigd. Werknemers in onzekerheid over hun arbeidsplaats bij veranderingen in de organisatie. Amsterdam: VU Uitgeverij.

Wanous, J., Poland, T., Premack, S. \& Davis, S. (1992). The effects of met expectations on newcomer attitudes and behaviors: A review and meta-analysis. Journal of Applied Psychology, 77 (3), 288-297.

Warr, P. (1984). Economic recession and mental health: A review of research. Tijdschrift voor Sociale Gezondheidszorg, 62 (8) 298-308.

Warr, P. (1987). Work, Unemployment and Mental Health. Oxford: Clarendon Press. 